\title{
Disclosure Level And Compliance With IFRSs: An Empirical Investigation Of Kuwaiti Companies
}

\author{
Abdullah Al Mutawaa, Public Authority for Applied Education and Training, Kuwait
} Aly M Hewaidy, Kuwait University, Kuwait

\begin{abstract}
This study empirically investigates the extent of compliance of Kuwaiti listed companies with IAS/IFRSs disclosure requirements, and provides evidence of the factors associated with the level of compliance. The factors examined are: company size, profitability, leverage, liquidity, type of industry, type of auditor, and company age. For this purpose a disclosure index is developed including 101 disclosure items representing 12 IASs. The annual reports of a sample of 48 nonfinancial companies carefully scrutinized against the disclosure index. The findings of the study indicate that the overall compliance level for the sampled companies averages 69\% of the disclosures required by the standards tested. Regression results indicate that only company size and type of industry have positive association with IAS-required disclosures and their coefficients are significantly different from zero. Other explanatory variables are found statistically insignificant.
\end{abstract}

Keywords: International financial reporting standards, Compliance, Disclosure level, Kuwait, Kuwait Stock exchange.

\section{INTRODUCTION}

C

nformation is essential for investors and other users in order to reach appropriate decisions. Market regulations need to be comprehensive to ensure availability of information to all investors at the same time. In the case of emerging markets Claessens et al. (1993) claim that foreign and domestic investors may be discouraged from equity investment because of market inefficiencies arising from unequal access to information. This could be an investment barrier, which might distract the attention of investors from the stock market.

Another reason that might discourage investors from emerging markets is financial disclosure. As indicated by Salter (1998), the average levels of corporate financial disclosure for companies in emerging markets continue to be significantly lower compared to those of developed markets. If emerging markets such as Kuwait, want to attract investors, these factors need to be considered by market regulators (Al-Qenae, 2000).

Ahmed and Nicholls (1994) argue that there are many incentives for disclosure in emerging economies such as lowering market risks and attracting direct foreign investment. On the contrary, there are also considerable reasons for not complying with mandatory disclosure requirements. Companies might not want to disclose sensitive information that may point to a problem when compared to other firms. In some cases management has incentives to suppress unfavorable information to withhold adverse information and to undertake preemptive buyouts of its own firm.

In the last years many countries all over the world adopted the international accounting standards (IASs)/international financial reporting standards (IFRSs) for the purpose of more quality of information disclosed in corporate annual reports. Kuwait is one of the leading countries in adopting IFRSs. The Ministry of Commerce 
and Industry in Kuwait has released the Ministerial Resolution No. 18 issued on 17 April 1990 that obligates all listed companies in the Kuwait Stock Exchange (KSE) to comply with IASs requirements. The present study aims to investigate the level of compliance of Kuwaiti listed companies with IFRSs-required disclosures, and the possible explanatory factors affecting the compliance level.

The outcomes of the study are expected to contribute to related prior empirical studies which have to date largely focused upon English-speaking and western contexts. The expected results may be also useful in that it can contribute to the development of better disclosure practices in Kuwait. The research results might lead to undertaking a similar research in other Gulf Council Countries especially where listed companies are required to prepare their annual reports based on the IFRSs requirements.

\section{EVOLUTION OF FINANCIAL REPORTING PRACTICES IN KUWAIT}

During the last decades, there have been crucial changes in accounting and auditing profession in Kuwait due to rapid economic growth and globalization. The government sets laws and regulations related to financial reporting practices and organizing accounting and auditing profession.

All Kuwaiti companies listed on the Kuwait Stock Exchange (KSE) are required to apply the International Financial Reporting Standards (IFRSs) as well as follow the related regulations and laws issued by three governmental bodies, namely: Ministry of Commerce and Industry (MCI), The Central Bank of Kuwait (CBK), and the KSE.

The MCI is responsible for checking compliance with commercial company law and other regulations. Overall, the MCI depends on the external auditor's report to assess the compliance with IFRSs requirements. However, the CBK depends on its auditors in order to inspect the compliance level and other legal requirements.

Regarding legislation in Kuwait, listed companies act in accordance with commercial company law and securities market law. For example, Law No. 6 of 1960 was issued to organize the accounting profession, it was amended by Law No. 3 of 1965 and by Law No. 5 of 1981 on the practice of auditing profession (Shuaib, 1998).

On June 28, 1981 a Permanent Technical Committee (PTC) of the MCI was created by Ministerial Decree No. 75/1981 to set accounting principles. Also, the PTC's framework and policy declared that developments in accounting profession in Kuwait depends on accounting practices used in developed countries whenever it is suitable to Kuwaiti business environment

As of January 1987, upon the PTC recommendations, the MCI issued Ministerial Resolution No. 4 of 1987 obligating all Kuwaiti companies to comply with three national accounting standards when preparing financial statements. These standards were related to financial statements, accounting for investment, and accounting for real estate. However, there are some criticisms directed to these standards regarding adequacy and sufficiency required by professional and academic standards (Al-Mudhaf, 1990; Shuaib, 1998, on Al shammari, 2005).

During April 1990 the MCI released the Ministerial Resolution No. 18 of 1990 obligating all listed companied in the KSE to comply with IFRSs requirements. The resolution has become effective in 1991. Adoption of IASs is expected to have a positive impact on the disclosure level and transparency, as well as enhancing comparability of financial statements of both domestic and international companies. The IASs are applicable given that there is no conflict with the local rules, regulations and business environment.

\section{RESEARCH OBJECTIVES AND QUESTIONS}

Given the preceding discussions, the main purpose of this study is to empirically investigate the level of compliance among Kuwaiti listed companies with IFRSs disclosure requirements. Specifically, the study aims at:

1. Identifying the overall level of compliance in the 2006 annual reports of Kuwait listed companies with the IASs/IFRSs disclosure requirements. 
2. Examining whether compliance level varies depending on company size, leverage, liquidity, profitability, industry type, type of auditor, and company age.

These two objectives can be summarized in a research question of the type: To what extent do Kuwaiti listed companies comply with IFRSs? And what are the major factors associated with and explaining the level of compliance with IFRSs-required disclosures?

\section{RESEARCH PLAN}

To achieve the research objectives, the remaining part of the study consists of three main sections. The first reviews the prior work related to level of disclosure and the major factors associated with company's compliance with required disclosures, and also develops the hypotheses related to these factors. The second section concerns with the research methodology including the process of sample selection and data collection, and the process of developing disclosure index (the research dependent variable). The third section provides the research results, analysis and discussions. A summary and conclusion are provided at the closing section of the study.

\section{LITERATURE REVIEW, INDEPENDENT VARIABLES AND HYPOTHESES}

Prior studies have examined the impact of various corporate characteristics on disclosure level on corporate annual reports. Among these characteristics are company size, profitability, listing status, leverage, liquidity, type of industry, type of auditor, ownership dispersion, and internationality. Based on the type of disclosure, these studies can be classified into three categories. The first category includes studies that test the association between corporate characteristics and mandatory disclosures (e.g. Wallace and Naser, 1995; Owusu-Ansah, 1998; Street and Gray, 2002; Glaum and Street, 2003; Owusu-Ansah and Yeoh, 2005; Al shammari et al, 2007). The second category includes studies that test the association between corporate characteristics and voluntary disclosures (e.g. Cooke, 1989; Meek et al, 1995; Hossain and et al, 1995; Hewaidy, 1998; Oyelere et al, 2003; and Alsaeed, 2006). The third category includes studies that test the association between corporate characteristics and total, both mandatory and voluntary, disclosures (e.g. Street and Bryant, 2000; Hassan et al, 2006).

The present study further explores the association between seven of corporate characteristics and mandatory disclosures (the disclosures required by the IFRSs) in Kuwait. These characteristics are company size, profitability, liquidity, leverage, type of industry, type of auditor, and company age.

\subsection{Company Size}

Several studies have identified company size as positively associated with level of disclosures. Considering mandatory disclosure studies, Wallace et al (1994) concluded that size, either measured by total assets or by total sales, is an important variable associated with level of disclosures. Also, company size as measured by total assets was found significantly associated with level of disclosures by Wallace and Naser (1995), Owusu-Ansah (1998), Ali et al (2004), Owusu-Ansah and Yeoh (2005), Al-Shammari et al (2007). On the other hand Ahmad and Nicholls (1994), Street and Gray (2002), and Glaum and Street (2003) found no association between company size and level of disclosures.

The present study further explores the relationship between company size and level of compliance with disclosure required by IFRSs. Total Assets and total revenues are chosen to measure company size. The following hypothesis tests the association between company size and extent of disclosures required by IFRSs.

H1a: Company size as measured by total assets is significantly associated with the extent of compliance with IFRS-required disclosures.

H1b: Company size as measured by total revenues is significantly associated with the extent of compliance with IFRS-required disclosures. 


\subsection{Profitability}

In prior research several ratios have been to measure company's profitability. Among the most common ratios are return on total assets, return on equity, and return on total revenues. The results of previous studies concerning the association between profitability and mandatory disclosures using one or more of these measures is rather mixed. Owusu-Ansah (1998), and Owusu-Ansah and Yeoh (2005) indicate a significant positive association, while, Wallace et al (1994), Street and Gray (2002), Glaum and Street (2003), and Ali et al (2004) provide no evidence of an association between company profitability and level of disclosures. On the other hand, Wallace and Naser (1995) reported a negative association between the two variables.

The present study further explores the relationship between profitability and level of compliance with disclosure required by IFRSs. Two measures are used for the profitability variable: return on total assets (ROTA), and return on equity (ROE). The following hypothesis tests the association between company profitability and extent of disclosures required by IFRSs.

H2a: Company profitability as measured by return on total assets is significantly associated with the extent of compliance with IFRS-required disclosures.

H2b: Company profitability as measured by return on equity is significantly associated with the extent of compliance with IFRS-required disclosures.

\subsection{Liquidity}

The term liquidity refers to the ability of a company to meet its obligations and commitments in the shortterm. Company's liquidity is concerned by several users of accounting information. Literature on the association between liquidity and level of disclosures is not conclusive. There is an argument that companies enjoying a higher liquidity are more likely to disclose more information than those suffering low liquidity (Cooke, 1989). On the other hand, it has been claimed that companies with weak liquidity might be induced to amplify their disclosure to mitigate fears and notify shareholders that management is aware of the problems (Wallace et al, 1994).

Empirical evidence provides mixed results for the association between company's liquidity and level of disclosure. Owusu-Ansah and Yeoh (2005) found a significant positive relationship between liquidity and level of disclosure. Wallace and Naser (1995), Naser et al (2002), Owusu-Ansah (1998), provided no evidence of such association. Wallace et at (1994) and Al shammari et al (2007), on the other hand, reported a negative association between these variables.

In further exploring the relationship between liquidity and level of compliance with disclosure required by IFRSs, the present study measures liquidity as the current ratio (total current assets/total current liabilities). This is the only liquidity ratio available in the KSE Investor Guide, and can be commonly used for all the sampled companies. The following hypothesis tests the association between liquidity and extent of disclosures required by IFRSs.

H3: Liquidity as measured by current ratio is significantly associated with the extent of compliance with IFRSrequired disclosures.

\subsection{Leverage}

It has been argued that firms with high debt tend to disclose more information to assure creditors that shareholders and management are less likely to bypass their convenient claims (Haniffa and Cooke 2002, in Ali et al, 2004). Al shammari et al (2007) pointed out that companies with higher leverage have, by definition, less equity and probably, in turn, relatively fewer shareholders. Consequently, they are more likely subjected to higher equity risk than companies with lower level of leverage and, therefore, are subjected to greater shareholder demand for information to assess both the probability that the company will meet its debt obligations and the degree of risk of future cash flows arising from their investments. 
Prior research provides conflicting findings regarding the association between leverage and the level of disclosure. For example, Belkaoui and Kahl (1978) and Al shammari et al (2007), identified leverage as a factor positively associated with level of disclosure. In contrast, Ahmed and Nicholls (1994) ; Wallace et al (1994); Wallace et al (1995); Ali et al (2004) and Hassan et al (2006) provide no evidence of such an association.

In further exploring the association between leverage and level of compliance with disclosure required by IFRS, the present study measures leverage as debt to equity ratio, and consequently tests the following hypothesis.

H4: Leverage as measured by debt to equity ratio is significantly associated with the extent of compliance with IFRS-required disclosures.

\subsection{Type of Industry}

Economic sector in which the company is operating may affect management interest toward releasing information in the company's annual report. Prior research provides conflicting results as to the association between type of industry and level of disclosure. While Bellkaoui and Kahi (1975), Wallace and Naser (1995), Naser et al (2002) found a significant association between type of industry and level of disclosur, Wallace et al (1994), OwusuAnsah (1998), Glaum and Street (2003), and Owusu-Ansah and Yeoh (2005) had no evidence of such association.

For further testing the relationship between type of industry and level of compliance with disclosure required by IFRSs, the variable industry is coded as investment, real estate, services, and manufacturing. The following hypothesis is employed.

H5: Type of industry is significantly associated with the extent of compliance with IFRS-required disclosures.

\subsection{Type of Auditor}

The accounting and auditing firms are primarily classified into two groups: large and small firms. In the light of the recent events, the large audit firms are the four largest international accounting and professional services firms, normally referred to as the Big 4, while small audit firms refers to those which operate domestically.

Prior research proves that level of disclosures may be associated with the type of auditor. Street and Gray (2002), and Glaum and Street (2003) reported a significant positive association between type of auditor and IAS disclosure requirements. Also, the results of Owusu-Ansah and Yeoh study (2005) indicated that auditor-type is consistently positively related to the extent of corporate mandatory disclosure. Wallace et al (1994) found a positive but insignificant association. On the other hand, Wallace and Naser (1995) reported a negative association between type of auditor and the extent of compliance with mandatory disclosure.

Many of the accounting firms operating in Kuwait are associated or affiliated with the Big 4. This resulted in creating two groups of accounting firms. One group of firms is associated with one of the Big 4, while the other group perform auditing without such an affiliation. Data collected revealed that $28(58 \%)$ of the sampled companies were audited by Kuwaiti accounting firms associated with one of the Big 4, the other 20 (42\%) of the sampled companies were audited by accounting firms with no association with the Big 4 . Therefore, the sampled companies are coded into:

- $\quad$ Companies being audited by accounting firms associated with one of the Big 4 .

- $\quad$ Companies being audited by other accounting firms.

The following hypothesis is tested:

H6: Type of auditor is significantly associated with the extent of compliance with IFRS-required disclosures. 


\subsection{Company Age}

It is believed that old companies might have improved its financial reporting practices over time, and therefore, they are expected to provide more disclosure than new companies. To the best of our knowledge, there are three mandatory disclosure studies which examined the association between company age and level of mandatory disclosures. Owusu-Ansah (1998) proved that company age has a statistically significant positive effect on mandatory disclosure and reporting practices 20 in Hong Kong. In New Zealand, Owusu-Ansah and Yeho (2005) found company age as the critical factor in explaining the extent of mandatory disclosure practices. Al shammari et al (2007) examined the association in the GCC countries and reached the same conclusion.

Company age is normally measured in term of number of years passed since listing or since foundation. In the present study the number of years passed since foundation is rather employed. The following hypothesis is consequently tested.

H7: Company age is significantly associated with the extent of compliance with IFRS-required disclosures.

\section{Research Methodology}

\subsection{Sample Selection and Data Collection}

The target population of the study is the companies listed on the KSE at the end of 2006. Year 2006 was chosen because it was the last year for which annual reports of the listed companies were filed and accessible at the KSE offices at the time of conducting the empirical work toward the end of 2007 and the beginning of 2008.

According to the Investor Guide, issued by the KSE, the total number of companies listed on the KSE consists of 176 companies, including 160 Kuwaiti companies, and 16 non-Kuwaiti companies. The 160 Kuwaiti companies are categorized in seven industrial sectors. These sectors are Banks (9 companies), Insurance sector (6 Companies), Investment sector (42 companies), Real Estate sector (28 companies), Manufacturing sector (25 companies), Service sector (45 companies), and Food sector (5 companies).

In the process of sample selection, non-kuwaiti companies (16) are excluded. Also, companies in the financial sectors (banks and insurance companies - 15) are excluded, as accounts and records of these companies are dissimilar to accounts and records of non-financial companies, and they are subject to a specific international accounting standard (IAS 30). Islamic companies (23 companies) are also excluded as they are subject to the so called "Shareah standards and regulations". The application of the Shareah standards and regulations will affect the accounting process regarding recognition, measurement, and presentation and disclosure.

The number of excluded companies amounted therefore to 55. A list of the remaining 121 companies was prepared, and the availability of annual report for each of them was checked. This has been undertaken by contacting/visiting both the financial officers of these companies, and the authorized office in the KSE, requesting a copy of the company's annual report for 2006. For any company not responding to these requests, an effort was made to obtain the annual report from the company's website, if it is available.

Table (1) shows the number of companies listed on the KSE on December 2006 and those excluded.

From the 121 companies a sample was selected. The selection process has been done at the sectoral level using the stratified random sampling approach. This process yielded 48 companies representing all the five economic sectors. As the food sector companies (5) are little, it has been decided to add them to the manufacturing sector, as they have similar operating activities. Table (2) shows number of the sampled companies classified by economic sector. 
Table (1)

Population from which sampled companies was selected

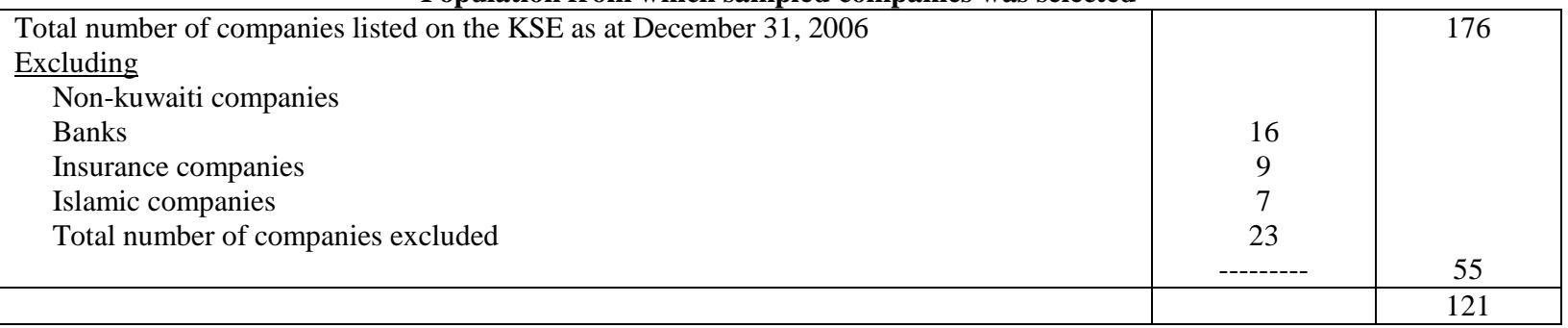

Sources: KSE, Investor Guide for the year ended 31 Dec. 2006,

Table (2)

Classification of Sampled Companies by economic sector

\begin{tabular}{|l|c|c|}
\hline \multicolumn{1}{|c|}{ Sector } & Total population & Sample \\
\hline Investment sector & 28 & 11 \\
\hline Real Estate sector & 23 & 16 \\
\hline Service Sector & 40 & 12 \\
\hline Manufacturing sector & 30 & $48(40 \%)$ \\
\hline Total & 121 & 9 \\
\hline
\end{tabular}

\subsection{Development of Disclosure index (Dependent Variable)}

Disclosure index refers to the degree or level of disclosure by each of the sampled companies. The disclosure index for each company is calculated by dividing the number of items actually disclosed in the company's annual report by the required/applicable items (i.e. the number of items that should be disclosed by the company).

In the process of calculating the disclosure index, a checklist for the International Accounting Standard Board (IASB)-required disclosures was developed. This was based on several sources including the text of the standards issued by the IASB, the checklist used in the prior research (Street et al, 1999; Street and Gray 2002, Al shammari et al, 2007), and the disclosure checklists published on the internet by Deloitte (2006), KPMG (2006). The IFRS illustrative consolidated financial statements for the year ending 31 December 2006 issued by the RSM International was also used in developing the checklist.

Reviewing the preceding sources as well as the Kuwaiti business environment, a checklist of 101 disclosure items was prepared. It includes the disclosure requirements related to the following IASs:

- IAS 1: Presentation of financial statements

- IAS 10: Events after balance sheet date

- IAS 14: Segment reporting

- IAS 16: Property, Plant and Equipment

- IAS 18: Revenues

- IAS 21: Foreign operations

- IAS 23: Borrowing costs

- IAS 24: Related party disclosure

- IAS 27: Consolidated financial statements and accounting for subsidiaries

- IAS 28: Accounting for investments in associates

- $\quad$ IAS 32 : Financial instruments

- IAS 34: Earning per share

On the checklist, each of the disclosure items was scored without weighting. Using un-weighted disclosure checklist in this study is based on the argument that with a big number of disclosure items examined weighted and 
un-weighted disclosure indexes will provide the same results (Marston and Shrives, 1996). The same study stated that the weighting process will reflect interests of a particular information users, hence, increasing the subjectivity in developing the disclosure indexes. Another study concluded that there is no significant difference between the results based on weighted and un-weighted disclosure indexes (Robbins and Auston, 1986).

Based on that, each item in the disclosure checklist used in this study was scored as disclosed (1), not disclosed (0), or not applicable (N/A). this means that, if a disclosure item is applicable to a company, such an item would score (1) if it appeared and disclosed in the company's annual report, i.e. a company was in compliance with the IAS-disclosure requirement, or scored (0) otherwise. An "N/A" is given to a disclosure item when it could be identified that a company is not disclosing such an item because there is no reason to disclose it (e.g. if property, plant and equipment of a company is stated at historical cost basis, then there is no reason to disclose information about revaluation amount of its property, plant and equipment as required by the IAS 16).

Each of the 48 annual reports was carefully scrutinized against the checklist to identify the sample companies' compliance with applicable disclosures. As a result of this process, each of the 101 disclosure items in the checklist was scored 1 if an item is applicable and disclosed, 0 if applicable but not disclosed, and N/A if it is not applicable. The compliance disclosure index for each company was computed as follows:

1. Calculate the applicable disclosures by summing items scored as 1 and 0 . This represents the number of items that a company is expected to disclose. The maximum number of applicable disclosures is 101 .

2. Calculate the actual disclosures by summing items scored as 1 . This represents the number of items that a company actually disclosed. The maximum number of actual disclosures is also 101.

3. Calculate the compliance disclosure index by dividing the number of actual disclosures by the number of applicable disclosures.

The following equation is used to calculate the disclosure for each company:

$$
D I N D=A C D \div A P D
$$

\section{Where: $D I N D=$ the disclosure index for a company $A C D=$ the number of items a company actually disclosed $A P D=$ the number of items a company should disclose}

The value of any index ranges from 0 to 1 , and the higher the value of index the higher the level of compliance with IASB-disclosure requirements

Using the same procedure, a compliance disclosure index was computed for each item in the checklist over all the sampled companies, and for each of the 12 group of items each of them representing an IAS.

\section{RESEARCH FINDINGS}

This section provides an analysis and discussion of the research results and findings. First descriptive statistics are presented, then the results of utilising correlation and multiple regression models are presented and discussed.

\subsection{Descriptive Statistics}

\subsubsection{Disclosure Level of the sampled companies}

Table (3) presents a distribution of the sampled companies according to the level of their compliance with the IASs disclosure requirements. Distribution has been done at the industrial sectoral level and for the total sampled companies. 
Table (3) distribution of the sampled companies according to the level of their compliance with the IASs disclosure requirements

\begin{tabular}{|c|c|c|c|c|c|}
\hline $\begin{array}{c}\text { Disclosure level } \\
\text { Range }(\%)\end{array}$ & $\begin{array}{l}\text { Investment } \\
\text { Companies }\end{array}$ & $\begin{array}{l}\text { Real estate } \\
\text { Companies }\end{array}$ & $\begin{array}{c}\text { Services } \\
\text { Companies }\end{array}$ & $\begin{array}{c}\text { manufacturing } \\
\text { Companies }\end{array}$ & $\begin{array}{c}\text { Total Sample } \\
\text { No. }(\%) \\
\end{array}$ \\
\hline Over $90 \%$ & 2 & --- & --- & --- & $2(4 \%)$ \\
\hline $90 \%-80 \%$ & 3 & -- & 1 & -- & $4(8 \%)$ \\
\hline $79 \%-70 \%$ & 5 & 2 & 9 & 6 & $22(46 \%)$ \\
\hline $69 \%-60 \%$ & 1 & 4 & 5 & 4 & $14(29 \%)$ \\
\hline $59 \%-50 \%$ & -- & 3 & $\mathbf{1}$ & 2 & $6 \quad(13 \%)$ \\
\hline Below 50\% & --- & --- & -- & --- & -- \\
\hline Total & 11 & 9 & 16 & 12 & $48(100 \%)$ \\
\hline Max. disclosure level & .967 & .782 & .822 & .767 & .967 \\
\hline Min. disclosure level & .641 & .538 & .593 & .560 & .534 \\
\hline Overall disclosure level & .793 & .637 & .717 & .685 & .693 \\
\hline
\end{tabular}

In line with the framework of analysis used by Lainez et al (1999, in Samaha and Stapleton, 2008) a distinction is made between four levels of company compliance with IASs requirements. High compliance, if the disclosure index is $80 \%$ or more, intermediate compliance between $60 \%$ and $79 \%$, low compliance between $40 \%$ and $59 \%$, and below $40 \%$ which reflects a substantial gap between company disclosure practices and the IASs requirements.

Given the results presented in table (3), and the above compliance level framework, the first note is that all sampled companies in all industrial sectors were found to have at least 50\% compliance level. This result suggests that Kuwaiti companies listed on the KSE complied with the majority of IASs disclosure requirements, with the lowest disclosure index $54 \%$ for a real estate company.

Table (3) also shows that about $75 \%$ of the sampled companies have a disclosure level between $60 \%$ and $79 \%$. This result indicates that most of the sampled companies meet the intermediate compliance level of the compliance framework used by Laizen et al, and the majority of these companies achieved a compliance level more than $70 \%$. It is also noticed that only 6 companies (12\% of the sampled companies) have a high compliance level (more than 80\%), and 5 of those 6 companies are investment companies. No company obtained an overall compliance rate of $100 \%$. Finally, data revealed that about $42 \%$ of the sampled companies achieved a disclosure compliance level less than $70 \%$. Overall, the average compliance rate was as low as $70 \%$.

These results indicate that Kuwaiti companies listed on the KSE did not comply with the disclosure requirements as amended by the IASB standards. This reinforces the usefulness of evaluation of the factors influencing companies' compliance with IAS-required disclosures, especially those companies with low disclosure level.

\subsubsection{Disclosure Score of the International Accounting Standards tested}

Table (4) summarizes the minimum, maximum, mean and standard deviation of the disclosure level for each of the 12 IASs. The minimum and the maximum represent case of one item or more within each standard, while the mean representing the extent of disclosure compliance with each IAS disclosure requirements.

The table shows that the highest level of compliance is .95 for standard related to revenues (IAS18). In line with compliance framework used by Lainez et al high level of compliance (averaging more than $80 \%$ ) was reported for IAS $10,18,27,28,34$. With the exception of standards 18 and 27 these results differ from what have been reported by Al shammari et al (2007). 
Table (4)

Level of compliance with the disclosure requirements of 12 IASs

\begin{tabular}{|c|c|c|c|c|}
\hline & Mav & Min & Moon & Ct $\mathrm{D}$ \\
\hline IAS 1: Presentation of financial statements & 100 & 020 & 7706 & 31264 \\
\hline IAS 10: Events after balance sheet date & 980 & 560 & 8333 & 23692 \\
\hline IAS 14: Segment reporting & .816 & .000 & .5406 & 33291 \\
\hline IAS 16: Property, Plant and Equipment & 1.00 & .00 & .7112 & 29986 \\
\hline IAS 18: Revenues & .980 & .920 & .9500 & .04243 \\
\hline IAS 21: Foreign operations & 1.00 & .000 & .2937 & .38055 \\
\hline IAS 23: Borrowing costs & .667 & .000 & .2303 & .37835 \\
\hline IAS 24: Related party disclosure & .898 & .020 & .6872 & .37881 \\
\hline IAS 27: Consolidated financial statements & .976 & .634 & .8475 & .15677 \\
\hline IAS 28: Acc. for investments in associates & 1.00 & .065 & .8123 & .36918 \\
\hline IAS 32* : Financial instruments & 1.00 & .240 & .7565 & .31714 \\
\hline IAS 34: Earning per share & 1.00 & .280 & .8150 & .35679 \\
\hline
\end{tabular}

Intermediate compliance (between $60 \%$ and $79 \%$ ) was found for standards 1, 16, 24, 32. Low level of compliance (.54) was noted for disclosure requirements of segment reporting (IAS 14), similar to the result reported by Al shammari et al (2007). Also a very low level of compliance (less than $30 \%$ ) was reported for standards 21 , and 23. This result suggests that more than $75 \%$ of the disclosure required by these two standards are not adhered to by the sampled companies. Detailed data collected from the financial statements of the sampled companies indicate that several disclosure items required by these two standards have been disclosed only by a few number of these companies. For example, 3 items were considered as the required disclosures by IAS 23. Of these three items, one of them has been disclosed by only one company, and no disclosure has been made for another one.

The preceding results indicate that compliance level varies across standards. A possible reason for this variation is the degree of difficulty associated with the application of these standards. Most of the standards with a high or intermediate compliance level is less difficult, and preparers of financial statements are familiar with the application of these standards as compared to those standards with low compliance level.

\subsubsection{Descriptive statistics for the explanatory variables}

Table (5)

Descriptive statistics for the explanatory variables

\begin{tabular}{|l|c|c|c|c|}
\hline & Max. & Min. & Mean & St. Dev \\
\hline 1. Company Size & & & & \\
$\quad$ Total Assets (KD) m & 716271 & 3664 & 141537 & 161817 \\
$\quad$ Total Revenues (KD) m & 477869 & 0.560 & 53957 & 102891 \\
2. Profitability & & & & \\
$\quad \quad$ return on equity & 0.471 & -0.416 & 0.147 & 0.169 \\
$\quad$ return on total assets & 0.323 & -0.235 & 0.087 & 0.093 \\
3. Liquidity (current ratio) & 16.600 & 0.108 & 2.940 & 3.843 \\
4. Leverage (debt to equity ratio) & 8.060 & 0.040 & 0.892 & 1.224 \\
5. Company age (No. of years) & 52 & 1 & 19.458 & 12.253 \\
6. Type of Auditor & 1 & 0 & 0.630 & 0.489 \\
7. Type of Industry & 1 & & & \\
$\quad$ Investment & 1 & 0 & 0.229 & 0.425 \\
$\quad$ Real estate & 1 & 0 & 0.188 & 0.394 \\
$\quad$ Service & 1 & 0 & 0.333 & 0.476 \\
$\quad$ Manufacturing & 0 & 0.250 & 0.438 \\
\hline
\end{tabular}

Table 5 shows a brief statistical description of the explanatory variables. The company size is measured by total assets and total revenues. The average size of the sample companies by total assets is KD 141537 million while the average size measured by total revenues is KD 53957 million. The standard deviation of this variable is large either measured in terms of total assets or total revenues. This means that measures of company size are not 
normally distributed. Therefore, and following prior research, the normal logarithm of this variable is taken to bring the distribution of this variable closer to normality.

Average profitability is $14.7 \%$ as measured by return on equity and $8.7 \%$ as measured by return on total assets. Average liquidity ratio is $294 \%$ reflecting a high liquidity of the sampled companies. Also the average leverage $89 \%$ measured as debt to equity indicating that the sampled companies are on average heavily leverage. The average age of the sample is 19.4 years since foundation. A normal logarithm of both liquidity and company age variables was also undertaken, and used in the regression model.

\subsection{Correlation Analysis}

The Pearson correlation matrix for the dependent and independent variables are presented in Table (6). The correlation matrix shows correlation between disclosure index and its explanatory variables, as well as the correlations among these variables. This will help checking the statistical relationship between the dependent and the independent variables, and whether there is any potential sign of collinearity.

The Pearson coefficient of the correlation between disclosure index and company size either measured in total assets or in total revenues is positive and significant at $1 \%$ and $5 \%$ levels of significance. Furthermore, the correlation between disclosure index and return on equity as a measure of profitability is positive and significant at the 5\% level. The correlation between liquidity and disclosure index is significantly negative. Two industrial sectors show a significant correlation with the disclosure index at the $1 \%$ level: investment sector (D1) with a positive correlation and real estate sector (D2) with a negative correlation. On the other hand all the correlation coefficients between the other variables and disclosure index are not significant.

Before proceeding to the regression analysis, it was instructive to check for the existence of collinearity among the independent variables. Table 6 shows that the correlation coefficients between disclosure index and total assets, total revenues, return on equity, liquidity, and type of industry both investment (D1) and real estate (D2) are higher than the correlation coefficients between disclosure index and every other independent variables. This suggests that collinearity among these variables may be an issue, and should be investigated. Table 6 shows that a large amount of significant collinearity $(\mathrm{P} \leq .02)$ among most of these variables. The correlation coefficient is .560 between total assets and total revenues, .605 between total assets and liquidity, .343 between total revenues and liquidity, and .366 between liquidity and type of industry (D1).

As a further check for collinearity, the variance inflation factor (VIF) was computed for each independent variable in the multiple regression model. Although there is no clear cut rule for what value of the VIF should be cause for concern, it has been suggested that collinearity is considered a problem when the VIF value exceeds 10 (Neter et al., 1983; Mendenhall and Sincich, 1989). Given the value of VIF presented in Table 6, it is noticed that with the exception of ROE and ROTA, collinearity among all other independent variables did not appear to be a serious problem in interpreting the regression results. A regression analysis had been run two times, once with dropping ROTA and another one with dropping ROE. The results of the two models are in favor of dropping ROTA. The value of VIF of ROE is lower than the VIF value of ROTA. Also, regression model including ROE instead of ROTA provides better results of the regression model outputs, such as values of F-ratio, $\mathrm{R}^{\mathbf{2}}$ and adjusted $\mathrm{R}^{2}$. Therefore, our analysis will be based on the regression results with dropping ROTA. Regression results are presented and analyzed in the following section. 
Table (6) Pearson Correlation of Dependent and Independent Variables

\begin{tabular}{|c|c|c|c|c|c|c|c|c|c|c|c|c|c|c|}
\hline \multirow{2}{*}{\multicolumn{2}{|c|}{ Variable }} & \multirow[b]{2}{*}{ TA } & \multirow[b]{2}{*}{ TR } & \multirow[b]{2}{*}{ ROE } & \multirow[b]{2}{*}{ ROTA } & \multirow[b]{2}{*}{ LEV } & \multirow[b]{2}{*}{ LIQ } & \multirow[b]{2}{*}{ AGE } & \multirow{2}{*}{$\begin{array}{c}\text { TYPE OF } \\
\text { AUD. }\end{array}$} & \multicolumn{4}{|c|}{ TYPE OF INDUSTRY } & \multirow{2}{*}{ DIS } \\
\hline & & & & & & & & & & INV & REAL EST & SERV. & MANUF. & \\
\hline \multirow{2}{*}{\multicolumn{2}{|c|}{ TA }} & 1 & & & & & & & & & & & & \\
\hline & & & & & & & & & & & & & & \\
\hline \multirow{2}{*}{\multicolumn{2}{|c|}{ TR }} & $.814(* *)$ & 1 & & & & & & & & & & & \\
\hline & & 0 & & & & & & & & & & & & \\
\hline \multirow{2}{*}{\multicolumn{2}{|c|}{ ROE }} & 0.226 & 0.2 & 1 & & & & & & & & & & \\
\hline & & 0.115 & 0.163 & & & & & & & & & & & \\
\hline \multirow{2}{*}{\multicolumn{2}{|c|}{ ROTA }} & 0.07 & 0.131 & $.930(* *)$ & 1 & & & & & & & & & \\
\hline & & 0.628 & 0.366 & 0 & & & & & & & & & & \\
\hline \multirow{2}{*}{\multicolumn{2}{|c|}{ Leverage }} & 0.069 & 0.062 & -0.02 & -0.132 & 1 & & & & & & & & \\
\hline & & 0.635 & 0.668 & 0.892 & 0.361 & & & & & & & & & \\
\hline \multirow{2}{*}{\multicolumn{2}{|c|}{ Liquidity }} & -0.27 & -0.191 & -0.246 & -0.188 & $-.304(*)$ & 1 & & & & & & & \\
\hline & & 0.058 & 0.185 & 0.086 & 0.19 & 0.032 & & & & & & & & \\
\hline \multirow{2}{*}{\multicolumn{2}{|c|}{ Age }} & 0.127 & 0.208 & 0.051 & 0.081 & 0.236 & -0.202 & 1 & & & & & & \\
\hline & & 0.381 & 0.146 & 0.723 & 0.574 & 0.098 & 0.16 & & & & & & & \\
\hline \multirow{2}{*}{\multicolumn{2}{|c|}{ AudSize }} & 0.16 & 0.209 & 0.191 & 0.172 & 0.221 & $-.347(*)$ & 0.001 & 1 & & & & & \\
\hline & & 0.266 & 0.144 & 0.184 & 0.233 & 0.123 & 0.014 & 0.996 & & & & & & \\
\hline \multirow{8}{*}{ 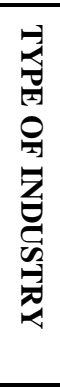 } & \multirow[t]{2}{*}{ INV } & 0.135 & -0.153 & 0.019 & -0.149 & 0.116 & -0.067 & -0.197 & -0.139 & 1 & & & & \\
\hline & & 0.352 & 0.288 & 0.898 & 0.302 & 0.422 & 0.643 & 0.171 & 0.336 & & & & & \\
\hline & \multirow[t]{2}{*}{ REAL EST } & 0.001 & -0.121 & -0.113 & -0.102 & -0.156 & -0.071 & 0.128 & -0.062 & -0.263 & 1 & & & \\
\hline & & 0.993 & 0.402 & 0.433 & 0.482 & 0.279 & 0.624 & 0.376 & 0.668 & 0.065 & & & & \\
\hline & \multirow[t]{2}{*}{ SERV } & 0.027 & 0.275 & 0.024 & 0.099 & 0.091 & -0.006 & -0.089 & 0.214 & $\begin{array}{c}- \\
.403(* *) \\
\end{array}$ & $-.336(*)$ & 1 & & \\
\hline & & 0.852 & 0.053 & 0.867 & 0.493 & 0.532 & 0.965 & 0.537 & 0.136 & 0.004 & 0.017 & & & \\
\hline & \multirow[t]{2}{*}{ MANUF } & -0.166 & -0.042 & 0.057 & 0.13 & -0.076 & 0.138 & 0.181 & -0.042 & $-.316(*)$ & -0.263 & $\begin{array}{c}- \\
.403(* *) \\
\end{array}$ & 1 & \\
\hline & & 0.25 & 0.77 & 0.697 & 0.366 & 0.6 & 0.339 & 0.209 & 0.77 & 0.025 & 0.065 & 0.004 & & \\
\hline \multirow{2}{*}{\multicolumn{2}{|c|}{$D I S$}} & $.415(* *)$ & 0.214 & $.286(*)$ & 0.115 & 0.034 & -0.207 & -0.013 & 0.152 & $.505(* *)$ & $-.403(* *)$ & 0.031 & -0.176 & 1 \\
\hline & & 0.003 & 0.135 & 0.044 & 0.427 & 0.813 & 0.149 & 0.928 & 0.291 & 0 & 0.004 & 0.833 & 0.221 & \\
\hline \multirow{2}{*}{\multicolumn{2}{|c|}{$V I F$}} & 4.791 & 4.68 & 12.404 & 12.634 & 1.479 & 1.42 & 1.348 & 1.286 & 2.119 & 2.624 & 2.071 & & \\
\hline & & & $\begin{array}{l}\text { orrelatic } \\
\text { orrelatio }\end{array}$ & $\begin{array}{l}\text { is signific } \\
\text { s signific }\end{array}$ & $\begin{array}{l}\text { at the } 0 \\
\text { at the } 0 .\end{array}$ & $\begin{array}{l}01 \text { level (2 } \\
5 \text { level (2 }\end{array}$ & $\begin{array}{l}\text { tailed) } \\
\text { ailed) }\end{array}$ & & & & & & & \\
\hline
\end{tabular}




\subsection{Regression Analysis}

Table (7) presents the regression equation and a definition of each variable in the equation. It also presents the regression results. These results show that F-ratio is 5.789 ( $\mathrm{P}=0.0000)$. This result statistically supports the significance of the regression model. Regression results show also that $\mathrm{R}^{2}$ is .578 , which implies that independent variables included in the model explain $57.8 \%$ of the variation in disclosure index.

Table (7) Regression results

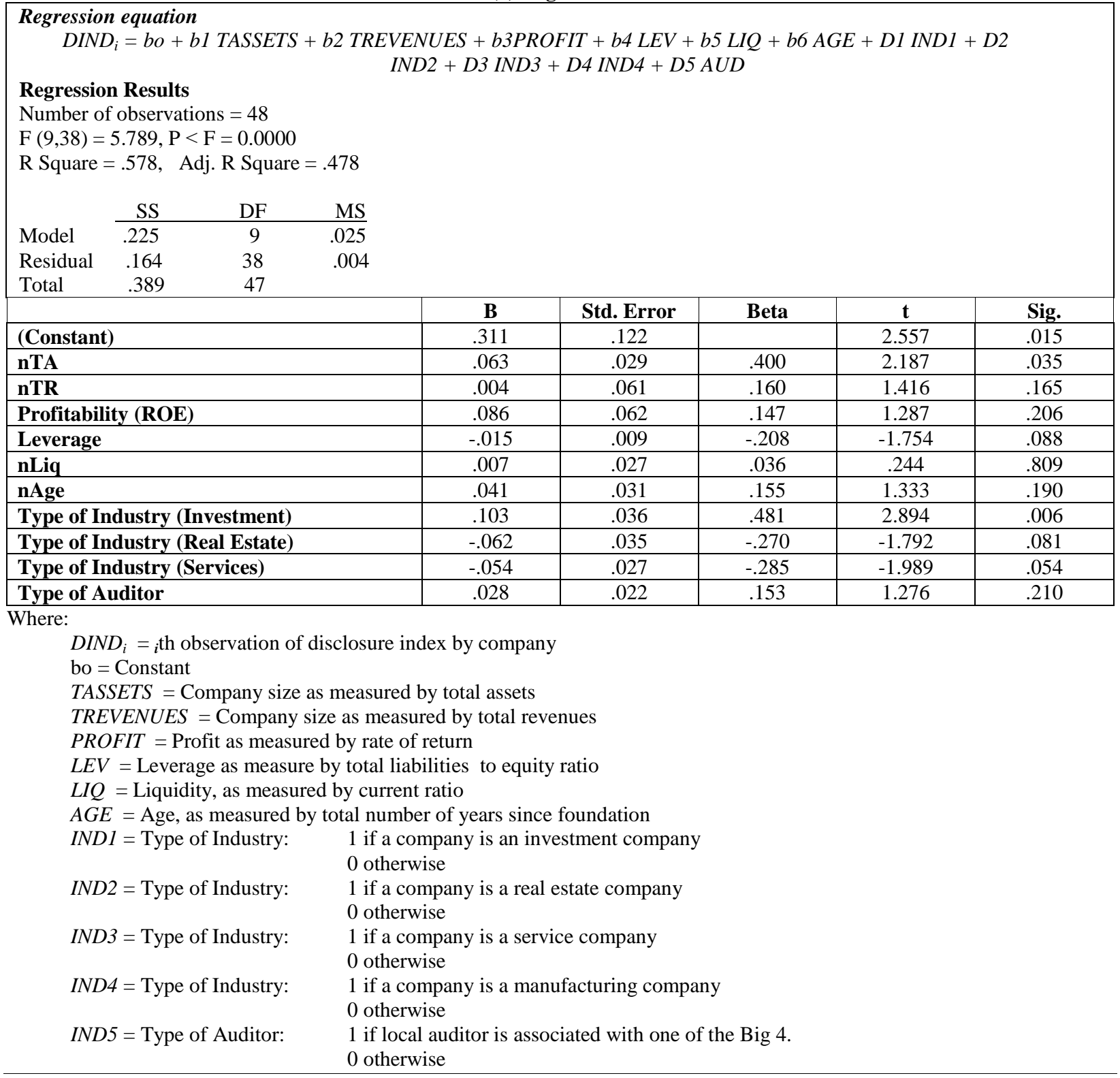

Regarding the association between independent variables and company's compliance with IAS-required disclosure, the results indicate that company size as measured in terms of total assets is significantly positively associated with the compliance level at a significant level less than 5\%. This result suggests that large companies are comply more with the IAS disclosure requirements than small companies. The positive association between 
company size and level of disclosures found in this study consists with the results reported by the majority of prior research (e.g. Wallace and Naser, 1995; Owusu-Ansah, 1998; Ali et al, 2004; Owusu-Ansah and Yeoh 2005; and Al-shammari et al, 2007). It is noticed that company size as measutred in terms of total revenues is positively associated but statistically insignificant.

Type of industry (Investment companies) was also found positively significantly associated with the level of compliance with the IAS-required disclosure at the $1 \%$ level of siginificance. This result confirms the results obtained from descriptive analysis. Table 3 shows that $12 \%$ of the sample (6 companies) reported the highest compliance level of disclosure (more than 80\%), and 5 of these companies are investment companies. The positive association between type of industry and level of disclosures consists with the results reported by prior research (e.g Bellkaoui and Kahi, 1975; Wallace and Naser, 1995; and Naser et al 2002).

Leverage was found to be negatively associated with disclosure compliance level, but not significant. Negative association of leverage may be explained by the argument that creditors (e.g. financial institutions - banks) do not need to rely on corporate reports, but often have access to information directly from the company. Therefore, companies with higher leverage tend to provide lower information than do lower leverage companies. Results of data analysis confirmed this argument. The highest leverage company in the sample (leverage ratio $800 \%$ ) has a low compliance level $(61 \%)$, while several companies having leverage ratio of $20 \%$ or less reported a compliance level more than $75 \%$.

Regarding profitability, table 7 shows that profitability as measured by ROE is positively associated with disclosure compliance level, however it is statistically insignificant. This finding confirms the prior research that provided mixed results for the association between company profitability and level of disclosure. The result of the present study consists with similar results reported by Wallace et al, 1994; Street and Gray; 2002; Glaum and Street, 2003, and Ali et al, 2004.

The result related to company age is different from expectation. Although there is a positive correlation between company age and compliance level, it is not statistically significant. The finding of the present study contradicts with findings reported by Owusu-Ansah, 1998; Owusu-Ansah and Yeho, 2005. This may be due to different locations of sample companies. Also, the present study examines the association between company age and IAS-required disclosures, while both of Owusu-Ansah study and Owusu-Ansah and Yeho study examine disclosure compliance with national accounting adopted by professional bodies in Hong Kong and New Zealand respectively. However, the result of the present study is consistent with Glaum and Street (2003) who found no significant association between company age and IASs disclosure requirements.

Same as profitability and company age, type of auditor was found associated positively with disclosure level, but statistically insignificant. This finding suggests that Kuwaiti companies audited by Kuwaiti accounting firms associated with one of the Big 4 do not provide information more than those companies audited by Kuwaiti accounting firms without such association. This result is consistent with Wallace et al (1994) who found a positive association but insignificant.

Overall, the findings of regression model suggest that large Kuwaiti companies provide more IAS-required disclosures than do small companies. Companies in the investment industry provide more IAS-required disclosures than do companies in the other three industries: real estate, services, and manufacturing. As indicated by the tstatistic all other independent variable is either negatively (leverage) or positively (remaining variables) associated with compliance level, but statistically insignificant.

\section{SUMMARY AND CONCLUSIONS}

This study aims at identifying the extent of Kuwaiti companies compliance with IASB-required disclosures. Moreover, it investigates the association between seven corporate characteristics and compliance level. To achieve these objectives, a sample of 48 non-financial Kuwaiti companies listed on the KSE was selected randomly from the relevant population which consists of 121 companies. The sample population represents all nonfinancial industrial sectors appeared in the Investor Guide issued by the KSE for the financial year ending 31 of December 2006. 
Based on the IASB-required disclosures and Kuwaiti business environment, a checklist of 101 disclosure items was developed. The checklist includes the disclosure requirements related to 12 IASs. Each of the 48 sampled companies' annual reports was carefully scrutinized against the checklist to identify the sampled companies' compliance. As a result of this process, disclosure index was computed for each of the sampled companies and for each item in the checklist over all the sample companies, and for each of the 12 IASs.

Results of statistical analysis indicate that the overall disclosure level for the sampled companies is $69 \%$ of the IAS disclosure requirements. The non compliance could be a result of economic reasons. Regression results indicate that only company size and type of industry have statistically positive association with IAS-required disclosures. As indicated by the t-statistic all other independent variables are either negatively (leverage) or positively (remaining variables) associated with compliance level, but statistically insignificant.

As any other researches, the present study has some limitations. Due to cost and time factors only seven explanatory variables were considered and examined for a sample of 48 non-financial companies, and annual reports for only one year ending 31 December 2006. Therefore, further research would be required. For example, testing the compliance level of financial companies, adding additional explanatory variables (e.g. listing status, corporate governance, culture and business environment); taking into account more than one year annual reports to explore the evolution of company's compliance level with IAS/IFRSs disclosure requirements. Another research area of interest is exploring the possible reasons explaining company's non compliance with disclosures required by the IAS/IFRSs.

In conclusion, there are crucial needs for more examination of the IAS/IFRSs and the approach of implementation by each state with special reference to the national culture, enforcement bodies, and business environment. This could help the IASB setting appropriate set of standards.

\section{AUTHOR INFORMATION}

Abdullah Al Mutawaa obtained his Master degree from University of Miami-U.S.A in 1997. He is a teacher of accounting, Faculty of Business Studies College, the Public Authority for Applied Education and Training, Kuwait. Currently, he is a PhD student at Durham University, UK. His research interest in financial reporting practices, accounting disclosures, and corporate governance in emerging markets.

Aly M Hewaidy obtained his PhD in Accounting from the University of East Anglia, UK. He is currently an associate professor of Accounting at Kuwait University in Kuwait. His research interests include financial reporting practices by the Egyptian companies and Kuwaiti companies, financial reporting by Islamic institutions, the application of international financial reporting standards.

\section{REFERENCES}

Ahmed, K. and Nicholls, D. (1994), "The impact of non-financial company characteristics on mandatory disclosure compliance in developing countries: the case of Bangladesh", International Journal of Accounting, 29, PP. 62-77.

Ali, M., K. Ahmed, and D. Henry. (2004). "Disclosure compliance with national accounting standards by listed companies in South Asia". Accounting and Business Research, 34 (3): PP.183-199.

AlSaeed, K. (2006). "The association between firm-specific characteristics and disclosure: The Case of Saudi Arabia". Managerial Auditing Journal, Vol. 21, No 5, PP. 476-496.

Al-Qenae, R. (2000). "Financial information and regulation in an emerging market: Empirical study of the Kuwait Stock Exchange". Business School. UK, University of Essex.

Al-Shammari, B. (2005). "Compliance with international accounting standards by listed companies in the Gulf CoOperation Council Member States: An empirical study". Business School. Australia, The University of Western Australia. 
Al-Shammari, B. et.al. (2007). "An investigation of compliance with international accounting standards by listed companies in the Gulf Co-Operation Council Member States". Social Science Research Network

Belkaoui, A. and A. Kahl. (1978). "Corporate financial disclosure in Canada". Research Monograph, No. 1, Vancouver: Canadian Certified General Accountants Association.

Cooke, T. E. (1989). "Voluntary corporate disclosure by Swedish sompanies". Journal of International Financial Management and Accounting 1, 2, PP.171-195.

Claessens, S., S. Dasgupta, and J. Glen (1993). "Stock Price Behaviour in Emerging Stock Markets", In Claessens, S., S. Dasgupta, and J Glen, Portfolio Investment in Developing Countries, World Bank Discussion Paper 228, Washington, DC, pp. 323-350.

Deloitte. "IFRS: Presentation and Disclosure Checklist 2006". www.iasplus.com.

Glaum, M. and D. L. Street (2003). "Compliance with the disclosure requirements of Germany's New Market: IAS versus US GAAP". Journal of International Financial Management and Accounting, 14 (1): PP. 64-100.

Haniffa, R. M. and T. E. Cooke. (2002). "Culture, corporate governance and disclosure in Malaysian corporations". Abacus, 38 (3): PP. 317-349.

Hassan, O. A. G., G. Giogioni, and P. Romilly. (2006). "The extent of financial disclosure and its determinates in an emerging capital markets: The case of Egypt". International Journal Accounting, Auditing and Performance Evaluation, Vol. 3, No. 1, PP.41-67.

Hewaidy, A. M. (1999). " Disclosure level in annual financial reports published by the Egyptian non-financial corporations: An empirical study". Al-Fkr Al-Mohasby, Accounting Dep., Faculty of Commerce, Ain Shams University, No. 1.

Hossain, M., M. H. B. Perera, and A. R. Rahman. (1995). "Voluntary disclosure in the annual reports of New Zealand companies". Journal of International Financial Management and Accounting, 6 (1): PP. 69-87

KPMG. "Accounting Checklist: IFRSs 2006". www.isa.kpmg.com.

Kuwait Stock Exchange, (2007), Investor Guide for the year ended 31 December, 2006.

Marston, C. L. and P. J. Shrives. (1996). "A review of the development and use of explanatory models in financial disclosure studies". Paper presented at the $19^{\text {th }}$ Annual European Accounting Association Congress, Norway.

Meek, G. K., C. B Roberts, and S. J. Gray. (1995). "Factors influencing voluntary annual report disclosures by US, UK and continental European multinational Corporations". Journal of International Business Studies, 26 (3): PP.555-572.

Mendenhall, W. and Sincich, T (1989). "A Second Course in Business: Regression Analysis". Reverside, New Jersy, Bellen Publishing Company.

Ministry of Commerce and Industry (1990), Resolution No. 18

Neter, J. et al. (1983). "Applied Linear Regression Models, Homewood, IL: Richard D. Irwin.

Owusu-Ansah, S. (1998). "The impact of corporate attributes on the extent of mandatory disclosure and reporting by listed companies in Zimbabwe". International Journal of Accounting 33, 5,PP. 605-631.

Owusu-Ansah, S. and J. Yeoh. (2005). "The Effect of Legislation on Corporate Disclosure Practices". Abacus 41, 1,PP. 92-109. 
Oyelere,p. et.al. (2003). "Determines of internal financial reporting by Newzland companies". Journal of International Financial Management \& Accounting, Vol.14, No 1, PP. 26-63.

Robbins, W. A. and K. R. Austin. (1986). "Disclosure quality in governmental financial reports: An assessment of the appropriateness of a compound measure". Journal of Accounting Research, 24 (2): PP.412-421.

RSM International. "IFRS illustrative consolidated financial statements for the year ended 31 December 2006". The worldwide Auditing, Tax \& Consulting Network.

Samaha, K. and P. Stapleton. (2008). " Compliance with international accounting standards in a national context: Some empirical evidence from the Cairo and Alexandria stock Exchanges". Afro-Asian Journal. Finance and Accounting, Vol. 1, No. 1, PP. 40-66.

Salter, B. Stephen (1998). "Corporate financial disclosure in emerging markets: Does economic development matter?". The International Journal of Accounting, Vol.33, No.2, pp.211-234.

Shuaib, A. (1998). "Evolution of accounting standards in Kuwait, the industrial bank of Kuwait". the IBK Papers, series No. 53.

Street, D. L., S. J. Gray, and S. M. Bryant. (1999). "Acceptance and observance of international accounting standards: An empirical study of companies claiming to comply with IASs", International Journal of Accounting, 34 (1): PP.11-48.

Street, D.L. and S. M. Bryant. (2000). "Disclosure level and compliance with IASs: A comparison of compliance with and without U.S. listings and filings". International Journal of Accounting 35, 3,PP. 305-329

Street, D. L., and S. J. Gray.(2002)." Factors influencing the extent of corporate compliance with international accounting standards: Summary of a research monograph". Journal of International Accounting, Auditing and Taxation 11: PP. 51-76.

Wallace, R. S. O., K. Naser, and A. Mora. (1994)."The relationship between the comprehensiveness of corporate annual reports and firm characteristics in Spain", Accounting and Business Research 25, 97, PP.41-53.

Wallace, R. S. O. and K. Naser. (1995). "Firm-specific determinants of the comprehensiveness of mandatory disclosure in the corporate annual reports of firms listed on the stock exchange of Hong Kong". Journal of Accounting and Public Policy 14, 4, PP.311-368. 
International Business \& Economics Research Journal - May 2010

Volume 9, Number 5

NOTES 